DOI 10.18551/rjoas.2021-10.12

\title{
NEW BUSINESS DEVELOPMENT STRATEGIES ON CULINARY PRODUCTS FOR MILLENNIALS IN BANJARMASIN, INDONESIA
}

\author{
Irwansyah Irwansyah, Halisa Novia Nour* \\ University of Lambung Mangkurat, Banjarmasin, Indonesia \\ ${ }^{\star}$ E-mail: novia.halisa@ulm.ac.id
}

\begin{abstract}
The program of creating new businesses or Wirausaha Baru, abbreviated as WUB in Banjarmasin, seeks to gradually realize the community's welfare through programs and activities that all parties can benefit from. New businesses in the current era require creative and innovative individuals, especially millennials. Therefore, this study aims to determine the role of millennials in new businesses and analyze their strategies in developing business. The study also aims to analyze WUB policies in Banjarmasin. This study used a descriptive qualitative method and was carried out at the Office of Cooperatives, Micro Enterprises, and Manpower of Banjarmasin. Informants were selected purposively to provide information about the development of new millennial businesses, while the object of this study was the development of culinary products in Banjarmasin. The informants were the Head of Cooperatives, Micro Enterprises, and Manpower Office of Banjarmasin, the Head of Youth and Sports Office, the Head of the WUB Association, business actors, consumers, and the community. This study applied analytical techniques consisting of data reduction, triangulation, and drawing conclusions or verification. The results of this study indicate that the Office of Cooperatives, Micro Enterprises, and Manpower of Banjarmasin and six other Regional Work Units (Satuan Kerja Perangkat Daerahor SKPD) in Banjarmasin cooperate with the WUB community as a forum for channeling support and information on new business development in Banjarmasin. In addition, the findings of this study are expected to contribute to the direction of new business development policies in Banjarmasin.
\end{abstract}

\section{KEY WORDS}

Wirausaha baru, millennials, culinary, South Kalimantan.

During the COVID-19 pandemic, an entrepreneurship program needs to be considered, and it has received strong attention from President Jokowi. This can be seen from his various speeches at various activities, such as launching the digital proficiency program in May 2021. President Jokowi said that independent businesses needed to be encouraged by assisting the community in taking advantage of technological advances digitally. This activity is an opportunity in the digital economy business. It is in line with the predictions of Bank Indonesia and Google (2020) that by 2025 Indonesia will become the largest digital economy driver in ASEAN with a digital economy value of USD 150 or more than IDR 2,040 trillion giving $10 \%$ added value to GDP. This is supported by the existence of Startup Unicorn, which has used a digital-based technology to drive various community businesses of various scales, most of which are run by millennials.

Entrepreneurship is widely known, especially for those who are engaged in business. The term entrepreneurship has long been discussed in Indonesia, both at the formal level in universities and government or at the non-formal level in the economic life of the community. Entrepreneurs are the pioneers of development, including reducing unemployment, creating new jobs, and improving the community's economy. In addition, entrepreneurship also contributes positively to other social values.

Banjarmasin is known as Kota Seribu Sungai or the City of a Thousand Rivers. It is the capital city of South Kalimantan Province, Indonesia, and one of the largest and most populous cities in Kalimantan. This city is also one of the big cities in Indonesia and the most populous city outside Java. Banjarmasin directs its development in five dimensions: the city of government, trade, ports, industry, and tourism. In this case, the Barito River becomes 
a strategic point and an icon for various community activities in Banjarmasin, including the tourism sector. This tourism area is characterized by various local specialties promoted as superior products, such as various traditional cakes that can only be found in Banjarmasin. Banjarmasin itself cannot be separated from the Barito River and its tributaries. Located at the Barito River and Martapura River junction, this city is very strategic for trading activities. As an icon and tourism area of Banjarmasin, the Barito River has become an attraction for sustainable tourism. This potential can be developed altogether with various products as main tourist attractions, such as sasirangan ${ }^{1}$ and local specialties like food, drinks, and cakes.

In Banjarmasin, a program known as the WUB (Wirausaha Baru) is intended to create new businesses. This program was launched by the government of Banjarmasin City that seeks to gradually realize the community's welfare through programs and activities that can directly benefit all people. This is also based on the Vision and Mission of the Mayor of Banjarmasin to increase competitiveness, added value, and business productivity by forming new businesses from 2016 to 2021 involving 2,500 new entrepreneurs. WUB involves seven Regional Work Units (Satuan Kerja Perangkat Daerahor SKPD),such as the Office of Cooperatives for Micro-Enterprises and Manpower, Youth and Sports Office, Culture and Tourism Office, Population Control Office, Family Planning and Community Empowerment Office, Social Service, Food Security Office, Agriculture, and Fisheries Office, and Trade and Industry Office. Each year, at least 805 participants are targeted to create strong, creative, and professional new businesses in Banjarmasin.

Since 2016, the implementation of the WUB program in Banjarmasin has brought great benefits to the community. In 2021, the Cooperatives, Medium Enterprises, and Manpower Office aim to optimize the WUB program. However, the general problem faced by micro and small business actors in Banjarmasin is the management or human resources with a low level of education and low motivation to master the technology. There are also issues on the floor production concerning raw materials, production processes, and non-optimal production results. There are also limited market, distribution, and target areas followed by financial problems related to bookkeeping or financial administration and unfavorable business climate.

To achieve the creation of 2500 WUB, the Banjarmasin City Government issued a technical guideline in 2018 based on the Banjarmasin Mayor Regulation Number 27 of 2016 concerning Recruitment, Selection, Training, Internships and Mentoring, Marketing, Network Development, and Monitoring Evaluation of Micro, Small, and Medium Enterprises (MSMEs). This technical guideline provides greater space for developing various MSMEs in Banjarmasin by operationalizing the digital economy. It is well recognized that one of the pillars of the national economy comes from MSMEs, yet the COVID-19 pandemic has affected MSMEs in some ways.

Based on the demographic map nationally and in Banjarmasin, millennials are currently the largest contributor to the population, making up $25.87 \%$ of Indonesia's total population of 270.2 million people (Central Bureau of Statistics, 2020). The millennial generation, gen Z, and post gen $Z$ fill the demographic bonus movement at around $82.98 \%$, dominating the population nationally and in Banjarmasin. Of the various development and business sectors that can be developed, millennials need to get an important portion to drive various conventional businesses to advance based on digital technology.

\section{METHODS OF RESEARCH}

This study was carried out at the Office of Cooperatives, Micro Enterprises, and Manpower of Banjarmasin, located at Jalan Pramuka, Komplek Smanda, Banjarmasin, to obtain data or information about the new business development strategies on culinary products for millennials in Banjarmasin. This study used a qualitative descriptive method to get a complete description or picture of something according to the view of the human being

\footnotetext{
${ }^{1}$ Sasirangan is a traditional cloth of South Kalimantan
} 
studied. Qualitative research deals with the ideas, perceptions, opinions, or beliefs of the people being studied (Basuki, 2006). The selection of informants is adjusted to the topics and problems studied. Informants were selected purposively based on the research objectives. The informants in this study were the Head of Cooperatives, Micro Enterprises, and Manpower Office of Banjarmasin, the Head of Youth and Sports Office, the Head of the WUB Association, business actors, consumers, and the community.

The data used in this study were primary data and secondary data collected using observations, structured interviews, and documentation. The data were analyzed simultaneously, starting with data reduction, triangulation, and drawing conclusions or verification.

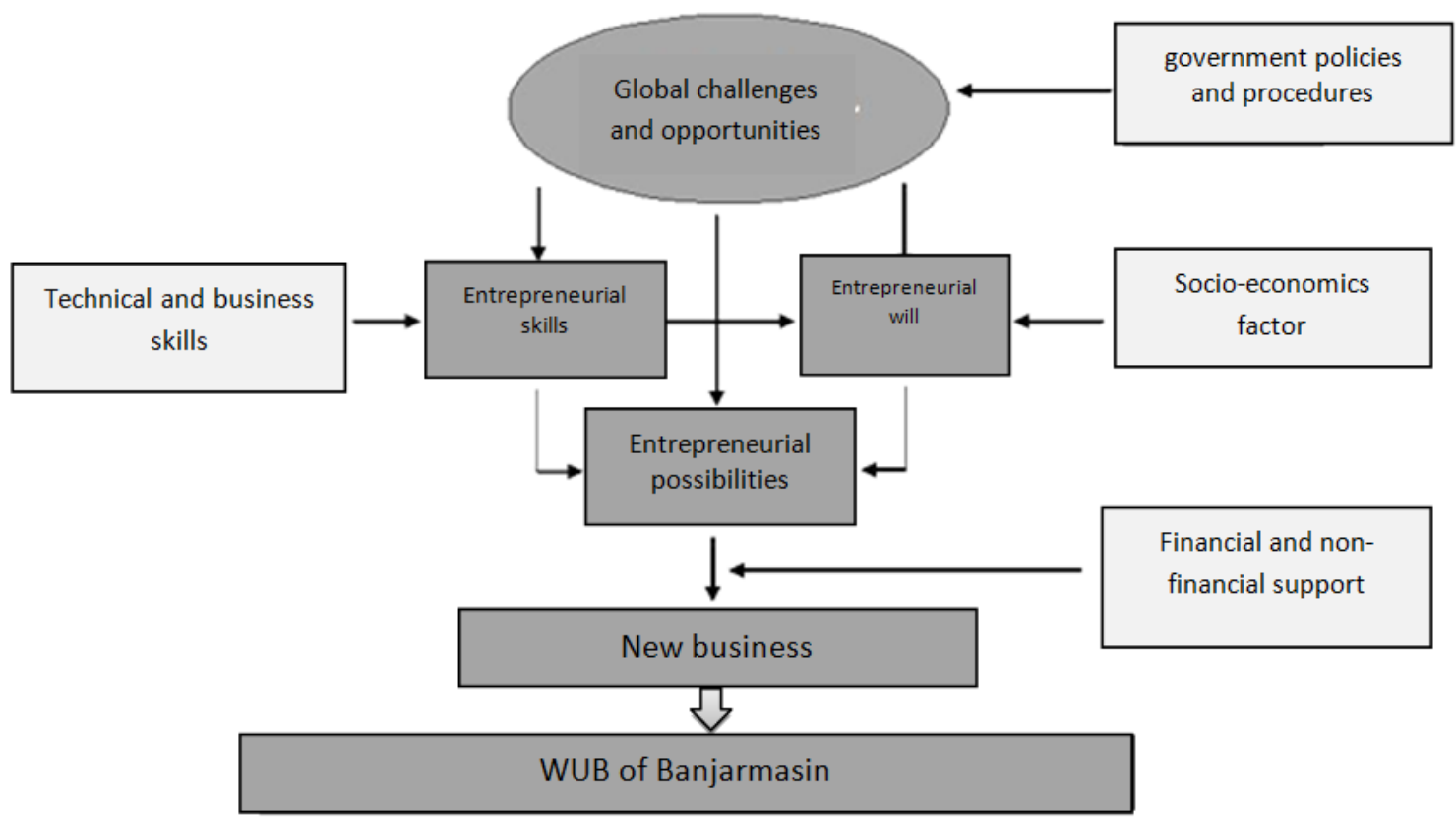

Figure 1 - Research Framework

\section{RESULTS AND DISCUSSION}

The Office of Cooperatives, Micro Enterprises, and Manpower of Banjarmasin. The Cooperatives, Micro Enterprises, and Manpower Office of Banjarmasin was established based on the Regional Regulation of Banjarmasin City Number 15 of 2008 concerning the establishment of the organization and work procedures of Municipal Police. The Cooperative Agency was formerly known as the Department of Cooperatives and Job Training. Since 2003, this agency has changed to the Department of Cooperatives and Manpower, and its activities increase every year. Therefore, in 2008, the Cooperatives Agency was changed to the Cooperatives and Micro, Small, and Medium Enterprises Office until 2016. At the end of 2016, the Cooperatives and Manpower Agency, separated in 2008, reunited again and became the Cooperatives, Micro Enterprises, and Manpower Office of Banjarmasin based on Government Regulation Number 18 of 2016 concerning Local Officials Arrangement.

The programs of the Cooperatives for Micro-Enterprises and Manpower Office of Banjarmasin are as follows:

- Quality and productivity development through training and education for jobseekers;

- Expanding job opportunities by disseminating information on job fairs;

- Creating a good climate for MSMEs through an expo center development;

- Entrepreneurship development program to increase competitive advantage by creating new WUB through training such as making pineapple jam, repairing laptops, printers, and cellphones, making sasirangan bags, making fruit juices, handicrafts, printing, doll souvenirs, knitting, making candied fruit, making cake, embroidery, and sewing; 
- Human resources development to build partnerships and networks by promoting cooperatives and MSMEs products such as exhibitions, capacity building for human resources, and MSEs or cooperative targets.

The WUB Banjarmasin Association is a community that supports new businesses in Banjarmasin and becomes a liaison between entrepreneurs and the Cooperatives, Micro Enterprises, and Manpower Office of Banjarmasin. The WUB Association provides TRAINING and financial assistance for new businesses. It also supports the government's program to create new businesses in Banjarmasin.

The WUB Association consists of the head and members who are also entrepreneurs. It has are 2000 members registered in 2021 - exceeding the government's target. That number is a combination of entrepreneurs in culinary, tourism, and other fields.

Millennials represent a social society that is literate and adaptable to technology. They tend to use technology to facilitate all activities. As a generation that grows with technological developments, millennials depend on technology in all its activities, from work, transportation, and payment transactions. Technology also plays a very important role in their interactions; they tend to use social media in social interactions. Millennial tends to be idealistic, entitled, and has high self-confidence. They can become a young economist with an entrepreneurial spirit, creativity, and innovation in the economic field. This generation can quickly adapt to new technologies and apply these new technologies in their lives. The adaptable and idealistic character of millennials is beneficial to face free trade in the global market. This means that they have to face a global business climate full of economic uncertainty. Millennials also collaborate easily with foreign countries because they are used to social media, where they make friends with people from various countries and languages.

The WUB Association and other government agencies work together to build new businesses in Banjarmasin to help the country's economic development. The millennial businesses in Banjarmasin are mostly in the creative industry. Therefore, millennials have helped to promote culinary products that are not widely known by the public. The interview results show that millennials can adapt quickly to technology, so the manifestation of this digital economy becomes easier. This is marked by the number of millennials who open and connect their FnB (food and beverage) and other businesses with startups, including Grab, Gojek, Tokopedia, Bukalapak, and so on. This indicates that millennials have taken a strategic position and modern strategy to market their products based on digital technology. They can even grow their businesses from home and thus minimizing the operational costs. Many creative industries are born from the ability and speed of millennials to transform the conventional ways of trading with technology. Today, millennials change their payment methods with digital wallets.

The adaptive thinking and action of millennials have made e-commerce in Banjarmasin grow rapidly. Millennials can adapt to the styles and needs of the market according to demographic conditions. Therefore, the use of technology in marketing places millennials as the driving force of the digital-based economy, both as producers and managers of their FnB businesses.

New Entrepreneurial Development Strategy. New businesses are very important to develop to be successful and run for a long time. In developing and in maintaining a business, a strategy is needed. Strategies in developing entrepreneurship are useful in dealing with world developments to face the global business climate of economic uncertainty. In this case, the Cooperatives, Micro Enterprises, and Manpower Office of Banjarmasin and the WUB Association work together to provide training and assistance for business actors to develop their businesses.

The Cooperatives, Micro Enterprises, and Manpower Office of Banjarmasin and the WUB Association conduct training and financial assistance to new entrepreneurs in Banjarmasin every year. In 2018, financial assistance was in the form of business equipment-financial assistance changes every year.

Findings show that millennials have attended various courses and other training that can support their business activities, and they are eager to improve their skills. However, their marketing is still constrained. They hope that their business can grow even more 
rapidly. They expect to get not only financial assistance and equipment but also knowledge on internal management so that the business can develop in a better direction.

New Business Development Strategy in Banjarmasin. One of the Mayor's programs in 2016-2021 is Small and Medium Enterprises Development. There was an increase in the number of Small and Medium Enterprises in Banjarmasin - it was 25 in 2016 and 150 in 2017 and 2018. The Vision and Mission of the Mayor of Banjarmasin are to increase competitiveness, added value, and business productivity by establishing 2500 WUB from 2016 to 2021. The study from Handayani (2019) mentions that the government has carried out several strategies in developing Small and Medium Enterprises in Banjarmasin, including facilitation, training, and promotion.

One of the seven SKPD that carry out the WUB program is the Youth and Sports Office. Its target is millennials aged 17 to 30 years. The Office has run the program from 2016 to 2021. It has fostered 427 people in its WUB.

The Cooperatives, Micro Enterprises, and Manpower Office of Banjarmasin as the coordinator of seven SKPD in Banjarmasin, and the one who created WUB, has carried out various entrepreneurial activities ranging from sewing, making sasirangan, and food processing.

In general, the target of 2500 new entrepreneurs has been surpassed as the city now has 3439 new entrepreneurs. These new businesses are still pioneering to develop a business attitude either as a group or individually. Meanwhile, the target to improve marketing skills will be carried out in stages because the government of Banjarmasin City has not paid much attention to the quality of its products. Although the quantity is fulfilled, the quality needs improvement - all stakeholders must collaborate to help these new entrepreneurs create quality products.

\section{CONCLUSION}

Findings confirm that the Cooperatives, Micro Enterprises, and Manpower Officeand thesix SKPD in Banjarmasin cooperate with the WUB community to develop WUB in Banjarmasin. SKPD assists in equipment, funds, and training to support the development and growth of new entrepreneurs in Banjarmasin. With the support of seven SKPD, new business actors are greatly helped. However, the COVID-19 pandemic has slowed down the development of these entrepreneurs. Fortunately, the target growth of WUB from 2016 to 2021 has been met, and millennials are involved in sharpening and enriching their digital technology adaptability skills.

The strategy to fulfill the quantity is considered to make a significant contribution to this effort. In general, business actors try to survive and begin to get used to current conditions. Young business actors are easier to adapt to environmental conditions. They must play an active role from the Cooperatives, Micro Enterprises and Manpower Office, the other six SKPD, and other business actors in Banjarmasin. Therefore, entrepreneurial activities in terms of financial management and marketing can be done effectively. This also requires digital technology in marketing to promote products outside the region.

\section{SUGGESTIONS}

Based on the conclusions above, it can be suggested that:

1. The Cooperatives, Micro Enterprises, and Manpower Office and six SKPD of Banjarmasin need to have more discussions with business actors, so training is given to the right target groups;

2. The government needs to conduct training on e-money payments because it will greatly support businesses during the current and future pandemic, where many consumers choose to have their orders online and delivered home;

3. The Cooperatives, Micro Enterprises, and Manpower Office of Banjarmasin and WUB of Banjarmasin should cooperate with the Cooperatives, Micro Enterprises, and 
Manpower Office and MSMEs in other cities and provinces for an exchange of entrepreneurial products in each region;

4. There must be training on standard packaging and product logos for better marketing. Such standards can become guidance in business management on an ongoing basis so that business actors can be independent or stable in financial and marketing management.

\section{ACKNOWLEDGEMENTS}

This study was supported by University of Lambung Mangkurat, especially the Faculty of Social and Political Sciences. We would like to thanks the Community Service Department (Lembaga Penelitian dan Pengabdian Pada Masyarakat) of Universitas Lambung Mangkurat for its support through the DIPA Grant of Program Dosen Wajib Meneliti (PDWM) of 2021 Number SP DIPA - 023.17.2.677518/2021 dated November 23, 2020.

\section{REFERENCES}

1. Anoraga, (2011). Pengantar Bisnis. Jakarta: Rineka Cipta.

2. Basuki, S. (2006). Metode Penelitian. Jakarta: Wedatama Widya Sastra.

3. Chell, E. (2013). Review of Skill and the Entrepreneurial Process. International Journal of Entrepreneurial Behaviour \& Research, 19(1), 6-31.

4. Guba, E.G \& Lincoln Y.S. (2005). Effective Evaluation. Improving The Usefulness Of Evaluations Result Through Responsive And Naturalistic Approaches. Jassey-Bass Inc. Publisher.

5. Hafsah, M.J. (2004). Upaya Pengembangan Usaha Kecil dan Menengah (UKM) Infokop Nomor 25 Tahun XX.

6. Handayani, N \& Rahma, Y. (2019). Strategi Dinas Perdagangan dan Perindustrian Kota Banjarmasin dalam Pengembangan Industri Kecil Menengah. Jurnal Studi Ekonomi, 10(2), $142-156$.

7. Iswahyudi, M. (2018). Minat Generasi Milenial untuk Berwirausaha. Jurnal Akuntansi dan Pendidikan, 7(2), 95-104.

8. Jhingan. (2007). Ekonomi pembangunan dan perencanaan. Jakarta: Raja Grafindo Persada.

9. Jusoh et al. (2011). Entrepreneur Training Needs Analysis Implications on The Entrepreneurial Skill Needed for Successful Entrepreneurs. International Business \& Economic Research Journal, 10 (1).

10. Lee et al. (2011). Corporate Entrepreneurship and Human Resource Management: Theoretical Background and A Case Study. International Journal of Manpower, 32 (1), 48-67.

11. Mangkuprawira. (2014). Manajemen Sumber Daya Manusia Strategik. Jakarta: Ghalia Indonesia.

12. Moekijat. (2011). Latihan dan Pengembangan Sumber Daya Manusia. Bandar Maju.

13. Moleong, L.J. (2011). Metodologi Penelitian Kualitatif. Bandung: PT Remaja Rosdakarya.

14. Nasution. (2011). Metode Research Penelitian Ilmiah. Jakarta: PT Bumi Aksara.

15. Patton, M.Q. (2009). Metode Evaluasi Kualitatif. Yogyakarta: Pustaka Pelajar.

16. Pio, R.J \& Johny, M. (2012). Studi Tentang Wirausaha Baru Berbasis Partisipasi Masyarakat. Jurnal IImu Administrasi, 8 (1).

17. Saiman, L. (2014). Kewirausahaan: Teori, Praktik, dan Kasus-kasus Edisi 2.Jakarta: Salemba Empat.

18. Schumpeter. (2012). Capitalism Socialisme \& Democracy (terj). Yogyakarta: Pustaka Pelajar.

19. Shane, S. \& Venkataraman, S. (2000). The promise of entrepreneurship as a field of research. Academy of Management Review. 25(1), 217-226.

20. Silalahi. (2009). Metode Penelitian Sosial. Bandung: PT. Refika Aditama. 
21. Suryana. (2013). Ekonomi Keatif, Ekonomi Baru: Mengubah Ide dan Menciptakan Peluang. Jakarta: Salemba Empat.

22. Widayati, dkk. (2019). Pengembangan Kewirausahaan Dengan Menciptakan Wirausaha Baru Dan Mandiri. Jurnal IImiah Manajemen Bisnis Dan Inovasi Universitas Sam Ratulani, 6(2), 98-105.

23. Zimmerer, Thomas W Dkk. (2008). Kewirausahaan Dan Manajemen Usaha Kecil Edisi 5. Jakarta: Salemba Empat.

24. Zotto, C \& Gustafsson, V. (2008). Human Resource Management as an Entrepreneurial Tool?", in Barret, R., and Mayson, S. (Eds), International Handbook of Entrepreneurship and HRM, Edward Elgar, Cheltenham. 